5. Nechaev, V. P., Ryazantsev, A. A. (2012). Modifikatsiya svoystv poverhnostnyih sloev tyazhelonagruzhennyih detaley gornyih mashin posredstvom plazmennogo uprochneniya [Modification of properties of surface coatings of heavy-loaded machine parts by means of plasma hardening]. Visnik Krivoriz'kogo natsional'nogo universitetu. Zbirnik naukovikh prats' - Journal of Kryvyi Rih National University, Vol. 32 123-127. (in Russian)

\title{
THE DOMINANT FACTORS DURING WATER TREATMENT IN THE BEVERAGE PRODUCTION
}

\section{Iryna Samchenko ${ }^{1}$ Svitlana Oliynyk ${ }^{2}$}

DOI: https://doi.org/10.30525/978-9934-588-11-2_14

Ensuring high quality and durability of products in alcoholic beverage production is achieved using the main ingredients: ethyl rectified spirit of the varieties of «Wheat tear» or «Luxury» and prepared water with high organoleptic indicators, balanced microcomponents cationic-anionic composition [1, p. 325].

At each stage of the technological process of production of alcoholic beverages, including water treatment, it is necessary to determine the dominant factors that will largely determine the quality of treated water [2, p. 7].

So the dominant factors for individual air-conditioning units of water during:

- mechanical purification are mechanical, structural, physico-chemical characteristics and chemical resistance filter media, the subtlety and flow velocity, the specific volume of the filtrate before reaching the limit values for opacity and tabarlet, timeliness of regeneration and the like;

- deironing and demangeat is structural and physico-chemical characteristics of filter materials, the filtration rate and the ability to modify a specific volume of the filtrate before reaching the limit values for iron and manganese content, determination of the possibility and efficiency of regeneration and the like;

- sorption purification are mechanical, structural, physicochemical and sorption characteristics of the sorption material, the limit values for sorbolene substances, the effectiveness of one or more sorbents to various directed action, the specific filtrate volume to achieve the limit values for permanganate Okinawans, the filtration rate, the possibility of regeneration, the impact of regenerating agents, etc.);

- mitigation is the physico-chemical characteristics of ion exchange material, the specific volume of softened water, filtration rate and regeneration efficiency, the minimum hardness value of treated water in the filtration cycle, the possibility of contamination of the ion exchanger with organic substances and the like;

\footnotetext{
${ }^{1}$ National University of Food Technologies, Ukraine

${ }^{2}$ National University of Food Technologies, Ukraine
} 
- denitrification processes are the physico-chemical parameters of the sorption material, the specific volume dentrification water, filtration rate and the ability and timeliness of regeneration, the minimum value for nitrogen-containing substances in the filter cycle and so on;

- demineralization vorotnavank method is material and selectivity of the membranes, adjusting the flow at permeate and concentrate in an automated manner, the flow rate of demineralized water, the use of regeneration and antiscalants, the need for blocks poperedni cleaning and the like;

- disinfection on the coefficient of efficiency, selectivity, specific output of disinfected water, prolonged duration of effect and the like;

- conditioning for optimal microcomponents cationic-anionic composition and to evaluate the effectiveness and homogeneity of the prepared water

- other stages of water treatment is the use of pumps, the influence of the material of the piping systems are available using membrane elements, and the like.

Identified dominant factors in water treatment contributes to obtaining treated water for the high stability of the finished product.

\section{References:}

1. Ivanov, S. V., Domaracki, V. A., Pribilski, V. L., etc. (2012). Innovative technology of fermentation products and wine-making: proc. (Ed. S. V. Ivanov). Kyiv, $487 \mathrm{p}$.

2. Kovalchuk, V. P. (2001). Of the comprehensive program of quality improvement of alcoholic beverages. Alcohol and tobacco, no 2, pp. 6-8.

\section{PRODUCTION OF FROZEN SEMI-FINISHED PRODUCT FOR A SMOOTHIE DRINK BASED STRAWBERRIES, DRIED APPLES AND OAT FLOCKS}

\section{Evgenia Sokolova ${ }^{1}$ \\ Larisa Tatar $^{2}$}

DOI: https://doi.org/10.30525/978-9934-588-11-2_15

A major role in strengthening health of people belongs to providing their full and healthy nutrition. A steady growth in the production of high-quality food products and beverages is required in order to accomplish this goal. Healthy nutrition is achieved by a balanced consumption of nourishing nutrients. The human body cannot receive a balanced diet that contains the entire set of essential substances because of the technological treatment of raw materials [1]. To ensure the proper and healthy diet, it is necessary to develop and create new products with high quality. Such products must to be balanced in their composition, as well as enriched with different

\footnotetext{
${ }^{1}$ Kharkiv State University of Food Technology and Trade, Ukraine

${ }^{2}$ Kharkiv State University of Food Technology and Trade, Ukraine 